\title{
Influence of Corporate Governance Disclosure on Tax Evasion Planning of Listed Company on the Stock Exchange of Thailand
}

\author{
Jutamas Kongsasone* \\ Candidate for Master's Degree of Business Administration, Faculty of Business Administration and Information \\ Technology, Rajamangala University of Technology Suvarnabhumi, Thailand \\ Kusuma Dampitakse \\ Faculty of Business Administration, Rajamangala University of Technology Thanyaburi, Thailand

\section{Dararat Phoprachak} \\ Faculty of Business Administration and Information Technology, Rajamangala University of Technology \\ Suvarnabhumi, Thailand \\ *corresponding author
}

\begin{abstract}
This study examined the influence of corporate governance disclosures for tax evasion planning of 216 Thai companies listed on the Stock Exchange of Thailand. Data were collected from good corporate governance reports, corporate social responsibility report, sustainability disclosures, annual report (form 56-1), annual financial statements, and notes to the financial statements in 2018. Quantitative research method was considered appropriate for this study using Multiple Linear Regression for data analysis. The results revealed that the good corporate governance disclosures based on the eight principles of 2017 have a positive influence on tax evasion planning from reduction in net accounting profit and net taxable profit, and calculation of tax ratio (TXO) per cash flow from operation (CFO) (74\%), at statistically significant level 0.01 . The size of good corporate governance disclosures has an influence on tax evasion planning at statistically significant level 0.01 . Good corporate governance principles of 2017 in this study have an influence on the tax evasion planning from reduction in net accounting profit and net taxable profits. By disclosing corporate governance information based on the eight principles of good corporate governance 2017, listed companies can be seen with fair practice in avoiding tax evasion as well as enhancing a company's image of transparency and reliability.
\end{abstract}

Keywords: good corporate governance, tax planning, tax evasion, tax evasion planning

Suggested Citation: Jutamas Kongsasone, Kusuma Dampitakse \& Dararat Phoprachak (2020). Influence of Corporate Governance Disclosure on Tax Evasion Planning of Listed Company on the Stock Exchange of Thailand. International Journal of Accounting, Finance and Education, Volume 1, Issue 2, pp. 1- 18. 


\section{Introduction}

Corporate governance (CG) is an effective management procedure that helps listed companies to enhance efficiency, transparency, and verifiability of the good corporate governance disclosures. The CG also creates confidence and reliability to shareholders and all stakeholders when making investment decisions (Puangyani et al., 2018). Most listed companies can have different approaches and patterns of the good corporate governance, depending on the discretion of the decisions or view of executives in formulating a good corporate governance policy and disclosing good corporate governance to public. This is one of the things that most company executives need to set as characterization of the disclosures. As the study of Tanchanpong (2015) found, good corporate governance has a positive direct and indirect influence on a company's performance based on the measurement of Tobin's Q value through the tax planning. Thus, good corporate governance can be an essential tool for all listed companies in showcasing good practices along with business performance in market.

In 2002, the Stock Exchange of Thailand started a campaign to support listed companies in realizing the importance and benefits of good corporate governance (The Stock Exchange of Thailand, 2012). It revised the latest corporate governance principles using corporate governance in the form of Corporate Governance Code (CG Code) for the Thailisted companies in March 2017 (The Stock Exchange of Thailand, 2017). Meanwhile, the Securities and Exchange Commission has issued the eight principles of the good corporate governance as a reporting guideline for the Thai-listed companies. This guideline aims to help Thai-listed companies create a sustainable value with transparency and responsibility of the board of directors (Chantadech, 2018). Moreover, it builds reliability to investors primarily as the practice of good corporate governance by the board of directors assures a highest level of management. By implementing the eight principles of the good corporate governance, the Thai-listed companies enhance credibility and reliability to its shareholders and stakeholders in the long run. This not only creates sustainable value to the listed company, it also meets the expectations of the company investors and builds reputation in the capital markets and society as a whole (The Stock Exchange of Thailand, 2017).

In accordance with the eight principles of good corporate governance for the Thailisted companies, the disclosure can assist companies to be seen with no intention to tax 
evasion planning. Companies following the eight principles of the 2017 reporting guidelines are doing a fair practice in taking full responsibility for corporate tax payment (Desai \& Dharmapata, 2006). In addition, Thai-listed companies align the corporate governance reporting to international practices, standards and formats. Accordingly, the good corporate governance disclosures can be used by investors in making investment decisions.

This study expects that corporate governance disclosures of Thai-listed companies meet the eight principles of the corporate governance 2017. As such, listed companies are assumed to be considered as a fair practice firm in avoiding tax evasion. It is further assumed that the corporate governance information based on the eight principles has an influence on tax evasion planning from reduction in net accounting profit and net taxable profit.

\section{Literature review}

\subsection{The good corporate governance principles 2017 for the Thai-listed companies}

Good corporate governance disclosures have been playing an important role in monitoring a company's performance and operation in relation to harnessing planning procedures (Salawu \& Adedeji, 2017). Good corporate governance principles for the accountability of the board of directors build reliability of corporate governance information to investors in terms of good practices. The eight principles of the corporate governance guidelines were adopted from the corporate governance principles of 2012 (Chantadech, 2018; The Stock Exchange of Thailand, 2017), shown in Figure 1.

\section{Figure 1}

Principles of good corporate governance for listed company

Principle 1: Establish Clear Leadership Role and
Responsibilities of the Board
Principle 2: Define Objectives that Promote Sustainable
Value
Creation


Originally there were five principles of corporate governance for the Thai-listed companies. The Stock Exchange of Thailand has added three principles in order to meet the international standard of good corporate governance. In 2017, the eight principles of good corporate governance termed as Corporate Governance Code (CG Code) was issued as a reporting guideline for the Thai-listed companies. The eight principles aim to build the reliability and trustworthiness of the board of directors to the stakeholders as well as enhancing sustainable value to the listed firms. In this regard, listed companies are required to disclose good corporate governance to build a good relationship with the stakeholders and adapt the business operations for the change in various circumstances for the long-term growth. The comparison between five original and the eight principles of corporate governance is shown in Table 1.

Table1

The changes in practices of good corporate governance principles

\section{Principles underlying CG code $\quad$ Similarity or difference from CG principles}

\begin{tabular}{l}
\hline Principle 1: Establish Clear Leadership Role and \\
Responsibilities of the Board
\end{tabular}

Responsibilities of the Board

Principle 2: Define Objectives that Promote Sustainable $\quad$ Does not disclose

Value Creation

Principle 3: Strengthen Board Effectiveness Content taken from Section 5 CG Principles (Board

Responsibilities).

Principle 4: Ensure Effective CEO and People Does not disclose

Management

Principle 5: Nurture Innovation and Responsible Business Content is taken from Section 3 CG Principles

(Stakeholder Roles)

Principle 6: Strengthen Effective Risk Management and Content is taken from Section 4 CG Principles

Internal Control

(Disclosure and Transparency)

Principle 7: Ensure Disclosure and Financial Integrity Content is taken from Section 4 CG Principles

(Disclosure and Transparency)

Principle 8: Ensure Engagement and Communication with Shareholders.

Content is taken from Section 1 CG Principles

(Shareholder Rights and Section 2 (Equitable

Treatment of Shareholders)

Source: Principles of good corporate governance for listed company (Chantadech, 2018; The Stock Exchange of Thailand, 2017)

The good corporate governance principles are considered as an appropriate practice that helps listed companies in creating sustainable value to meet the expectations of 
investors, capital markets and society as a whole (The Stock Exchange of Thailand, 2017). This becomes an important factor for the Thai-listed companies in creating strong relationships with their stakeholders. However, winning the trust of the stakeholders is not sufficient for good corporate governance.

Good corporate governance has both direct and indirect negative influences on a company's performance. It is a fact that investors look for good corporate governance disclosures to support their investment decisions. By disclosing good corporate governance, listed companies can be seen as a fair practice firm in avoiding tax evasion planning (Tanchanpong, 2015). Most listed companies in the Stock Exchange of Thailand are concentrated on disclosing good corporate governance to be known as avoiding tax evasion of firms in the eye of stakeholders. In this relation, tax planning, in form of tax avoidance can be a significant dimension in creating more tension between a company and its investors. Thus, corporate governance information in a company's disclosures can have a positive influence on tax planning.

There are numerous studies that associate corporate governance to the various aspects of tax planning. For instance, Salawu \& Adedeji (2017) found that the corporate governance score of non-financial corporations has a positive correlation to tax planning. Similarly, Srisakonkij (2019) found that the tax planning ratio has a positive relationship with the prices of common stock wherein high tax planning strategies impact on the price of common stock. However, the size of the board of directors including the proportion of independent directors and the type of auditors incorporated in the good corporate governance disclosures have no relationship with the company's performance (Thadthiam \& Promma, 2020).

\subsection{Tax evasion planning from reduction in accounting profit and taxable profit}

\subsubsection{Tax planning}

Tax planning is a comprehensive preparation for accurate tax payment in which companies can obtain various tax benefits based on the tax law of a country. It helps a company evaluate appropriate corporate tax payment and avoid penalty fees due to tax evasion (Tanchanpong, 2015). However, tax planning for a corporate perspective can be seen as a strategy for tax evasion. It can consider illegal benefits for corporate tax evasion (Dyreng et al., 2007), such as using a tax planning method to reduce profits in order to reduce 
corporate tax. This is also known as Tax Aggressive Planning (Coppens \& Peek, 2005). The Tax Aggressive Planning is used for a reduction in accounting profit management which can affect reduction in taxable profits (Goncharov \& Zimmermann, 2006). A company with an increasing accounting income resorts to reduce tax income for a particular period. In this case, company may use the inconsistency between accounting standards and tax principles (Frank et al., 2009). Multinational companies could have a chance to avoid corporate tax payment by recording accounting transactions based on the accounting standard applied in other countries along with different tax laws of the countries. This helps the company to avoid corporate tax payments which is known as tax avoidance or tax evasion (Rego, 2003). Multinational corporations located in a lower tax country enable to allocate a portion of income from a company of the country with higher corporate taxes (Collins et al., 1998). Lanis \& Richardson (2011) found that management acting on behalf of shareholders enables a company to reduce taxable profits using a Tax Aggressive Planning (Chen et al., 2010). Although this helps increase in the shareholders' benefits, this results in increases company costs including transaction costs, reputation cost, and political costs. In addition, a company with low level of good corporate government intends to use more proactive tax planning in order to avoid corporate tax payment. In this case, shareholders may not approve executives to do anything regarding proactive tax evasion planning.

\subsubsection{Tax evasion planning}

Tax evasion refers to the intention of avoiding corporate tax by dishonest or illegal manner such as preparing two sets of accounts, disclosing lower amount of sales or incomes, reporting higher expenses, issuing a tax invoice without rights, intending to avoid reporting financial information, and using counterfeit stamp on the tax reports (Chotsuwan \& Thongkong, 2019). This includes (1) intending to fill tax return report or responding untruthful answers to required questions, creating incorrect information and incorrect evidence having intention of fraud or dishonesty to avoid or attempt to avoid taxation, (2) intending to neglect or not filing or trying to avoid taxation, (3) attempting to avoid or intentionally avoid Value Added Tax, and (4) having intention to commit the fraudulent by using counterfeit stamps, and used or unused stamps on the tax reports. Companies committing tax evasion must pay extra fines as a civil penalty resulting from a criminal 
cases. In this case, convicted companies cannot use the fines or penalty expenses to be recorded as expenses in order to calculate taxable profits or losses.

Although proactive tax evasion planning creates an opportunity to generate high profits, it is not the best tax planning policy for every company. It depends on whether the benefits are worthy enough compared to costs or expenses. Some companies offer benefits to the management to find ways for planning tax evasion. This results to an increased level of tax evasion planning (Desai \& Dharmapata, 2006). Since the concept of Corporate Social Responsibility (CSR) was introduced to the listed firms, the relationship between a company and its stakeholders emphasized the improvement in social activities including government agencies, political groups, suppliers, employees, and customers. Company that pays proper taxes can be considered as a CSR in the eyes of the stakeholders. In this relation, a CSR facilitates a company to describe the relationship between good corporate governance and tax planning. Thus, a CSR firm is considered a socially responsible organization complying with legal actions and reducing tax evasion planning.

\subsubsection{Reduction in net accounting profit and net taxable profit and tax ratio per cash} flow ratio

As the main purpose of financial reports is for tax planning, a company prepares income statements for the same purpose. There are two factors of taxation influencing management on financial reporting which include tax incentives and tax basis. The former has a strong influence on the financial statements. When accounting practice is consistent with tax practice, tax accounting regulations comply with financial accounting rules. On the other hand, the latter has a strongly negative impact on tax management due to the contract used for accounting and tax computation basis. It causes more conflicts in the financial reports (Ball \& Shivakumar, 2005). Although a company enables to manage earnings in accordance with the tax principles to avoid corporate tax, company may not do so. If there is difference between profits according to accounting and tax principle, it can be targeted by the government (Badetscher et al., 2009; Cloyd, 1995; Mills, 1998). This can also be tempered by external editors (Hanlon et.al, 2006). As tax incentives reduce the benefits from earning management, it also allows some countries to support investment through reduction in tax rates and exemption of partial income (Coppens \& Peek, 2005). This is commonly referred to 
as tax evasion which a company discloses unusually high profits and subject to low tax rates under tax law (Sullivan, 2004).

Income statement schemes help listed company to reduce tax revenues. Companies are looking for a way to hide tax evasion from users of financial statements. Some companies may not disclose income generated from operations. Therefore, there is an opportunity to avoid the disclosure of any information in relation to tax evasion (Hope et al., 2013). Tax evasion does not mean the company is doing wrong. There are a variety of tax laws that allow companies to reduce the amount of corporate taxes. Somehow, tax laws are not clear and actually complicated in practice. Companies may face with incomplete transactions which results in losing their returns in order to pay corporate taxes (Dyreng et al., 2007). In relation to this, tax ratio per cash flow from operation (TAX / CFO) is used for the calculation of the net income from operation (Klinphanich et al., 2019; Tanchanpong, 2014). Income and expenses are recorded based on accrual basis, which have not yet been actually received or paid (Zimmerman, 1983). Meanwhile, the cash flow statement presents the noncash income and expenses incorporated in the actual performance of a company. Calculation of net cash flows from operating activities is not affected by the profit management based on the accrual basis (Zimmerman, 1983). When a company has low tax expenses, this can increase the cash flow from operating activities. This results to a lower value in tax ratio per cash flow from operation.

Based on the accounting standards and principles, income and expenditures are recognized using accrual basis while taxation principles applies eligibility criteria under the revenue. This can be written as an equation for adjusting accounting profit as taxable profit (Chotsuwan \& Thongkong, 2019). The good corporate governance mechanism helps a company to comply with the tax laws such as a tax planning mechanism. Companies using the tax planning strategies may face a significant concern of stakeholders and society as a whole. Corporate governance principles are not considered tax planning strategies to be included in the disclosures. Therefore, listed companies need to ensure that corporate governance disclosures meet the expectations of stakeholders and society in order to be considered as a good corporate governance firm (Ibrahim et al., 2003). Tax planning is considered as an important factor for effective corporate disclosures. An influence of good corporate governance principles should have an impact on tax evasion planning from 
reduction in accounting net profit and net taxable profit. Listed companies disclosing corporate governance information under the eight principles can be considered as avoiding tax evasion planning significantly. Thus, this study has one hypothesis (H1) underlying the review of previous studies and research framework as given below.

H1: The influence of good corporate governance principles positively affects tax evasion planning from reduction in net accounting profit and net taxable profit

\section{Figure2}

Research conceptual framework

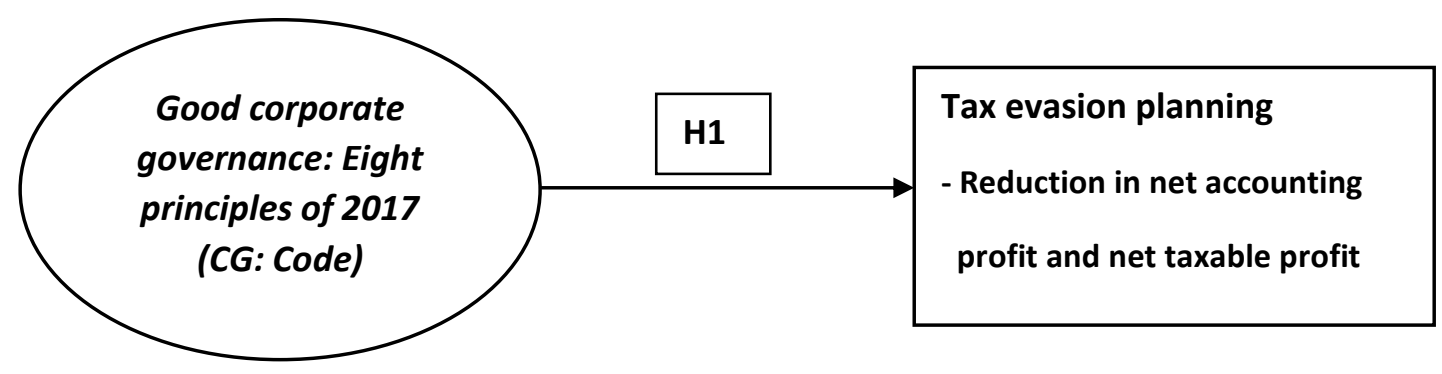

\section{Methodology}

Quantitative research method was considered appropriate for data analysis. Data were collected from the Annual Report (Form 56-1), Financial Statements, and Notes to Financial Statements of Listed Companies in 2018. The focus of this study was to examine the influence of good corporate governance disclosure towards tax evasion planning of the Thailisted companies. The study designed a worksheet format to measure the statistical disclosure of good corporate governance information of listed companies underlying the Corporate Governance Code for Listed Companies 2017 (Chantadech, 2018). The influence on tax planning of listed companies was investigated towards tax evasion planning from reduction in accounting profits and taxable profit. The tax ratio (TXO) was divided by the cash flow from operation (CFO) (Tanchanpong, 2014). 


\subsection{Sample selection methods}

A total of 216 samples were selected from the total population of 468 listed companies in Thailand. The random sampling methods were employed to evaluate 216 samples using Yamane's formula (Yamane, 1973) shown in Table 2.

\section{Table 2}

Population and sample groups used in the research

\begin{tabular}{lccc}
\hline \multicolumn{1}{c}{ Industry sector } & Total population & Measurement & Sample \\
\hline \hline 1. Agro industry and food industry & 52 & $(52 \times 216) / 468$ & 24 \\
2. Consumer goods industry & 39 & $(39 \times 216) / 468$ & 18 \\
3. Industrial Products Industrial & 89 & $(89 \times 216) / 468$ & 41 \\
4. Real Estate and Construction & 86 & $(96 \times 216) / 468$ & 44 \\
6. Resource Industry & 47 & $(47 \times 216) / 468$ & 22 \\
7. Service industry & 110 & $(110 \times 216) / 468$ & 51 \\
8. Technology Industry & 35 & $(35 \times 216) / 468$ & 16 \\
\hline \multicolumn{1}{c}{ Total } & $\mathbf{4 6 8}$ & & $\mathbf{2 1 6}$ \\
\hline \hline
\end{tabular}

Source: The Stock Exchange of Thailand (2018) edited by the researcher

\subsection{Data collection methods}

The study designed a recording data form to identify the good corporate governance practices of sampling companies using eight principles of good corporate governance 2017. Each sentence relevant to the eight principles of the CG Code was given a one (1) mark. Corporate governance information in the disclosures of samples in line with the eight principles of the good corporate governance principles was counted. Dependent variables were identified from the financial statements in terms of tax rate ratio as per cash flow from operation, taxable expenses. Taxable expenses were collected from the statement of comprehensive income and the net cash flow from operation was identified from cash flow from operation. The calculation steps are: 
Taxable expenses / Net cash flow from operation) X 100

The analysis was performed as follows:

Each aspect of good corporate governance $=$ The maximum number of collective sentences of the samples

Where conditions are as follows: 0 <sentences analysed from each aspect > 1

\section{Findings and Discussion}

The results answered the $\mathbf{H 1}$ that an influence of good corporate governance principles positively impacts tax evasion planning from reduction in net accounting profit and net taxable profit, and calculation of tax rate ratio with cash flow from operating activities of sample companies. The results were relevant with the theory and empirical data considering the chi-square statistic 0.00 . The degree of freedom (df) was significantly different from zero $(\mathrm{p}$-value $=1.000)$ based on the standard, greater than 0.05 . The relative chi-square value was no more than 2. When considering the consistency from the Harmony Index (GFI), the value was 1.00; the AGFI value was 1.00; the RMSEA value was 0.00, as shown in Table 3.

\section{Table 3}

Influence of good corporate governance on tax planning towards tax evasion trends

\begin{tabular}{ccccc}
\hline Variables & Standard Coefficient & Standard Errors & t-values & Sig. \\
\hline CG1 & 0.11 & 0.22 & 3.31 & $.00^{* *}$ \\
CG2 & 0.18 & 0.19 & 7.51 & $.00^{* *}$ \\
CG3 & 0.16 & 0.17 & 5.36 & $.00^{* *}$ \\
CG4 & 0.24 & 0.18 & 10.29 & $.00^{* *}$ \\
CG5 & 0.16 & 0.21 & 5.86 & $.00^{* *}$ \\
CG6 & 0.33 & 0.17 & 13.66 & $.00^{* *}$ \\
CG7 & 0.15 & 0.18 & 5.02 & $.00^{* *}$ \\
CG8 & 0.24 & 0.18 & 8.02 & $.00^{* *}$
\end{tabular}

Multiple R = 0.74**, R Square = 0.55, Adjusted R Square = 0.52, Std. Error $=0.26$

Note: * Statistical significance at the .05 level $(1.960 \leq t-$ value $<2.576)$

** Statistical significance at level. $01(t-$ value $\geq 2.576)$ 
The influence of good corporate governance on tax evasion planning also shows that good corporate governance enables to forecast tax planning evasion, 74\%. When analysing good corporate governance for each aspect, this study found that good corporate governance has an influence on reduction in tax evasion planning. CG6 was at highest level of $0.33^{* *}$, followed by CG4 and CG8 $(0.24 * *)$, CG2 $\left(0.18^{* *}\right)$, CG3 and CG5 $\left(0.16^{* *}\right)$, CG7 $\left(0.15^{* *}\right)$, and CG1 $\left(0.11^{* *}\right)$, respectively at statistically significant level 0.1 as follows.

$$
\begin{aligned}
\mathrm{Z}_{\mathrm{CFO}}= & 0.11(\mathrm{CG} 1)+0.18(\mathrm{CG} 2)+0.16(\mathrm{CG} 3)+0.24(\mathrm{CG} 4)+0.16(\mathrm{CG} 5)+ \\
& 0.33(\mathrm{CG} 6)+0.15(\mathrm{CG} 7)+0.24(\mathrm{CG} 8)
\end{aligned}
$$

\section{Figure 2}

Analysis of the influence of good corporate governance $(C G)$ on the tax evasion planning from reduction in net accounting profit and net taxable profit

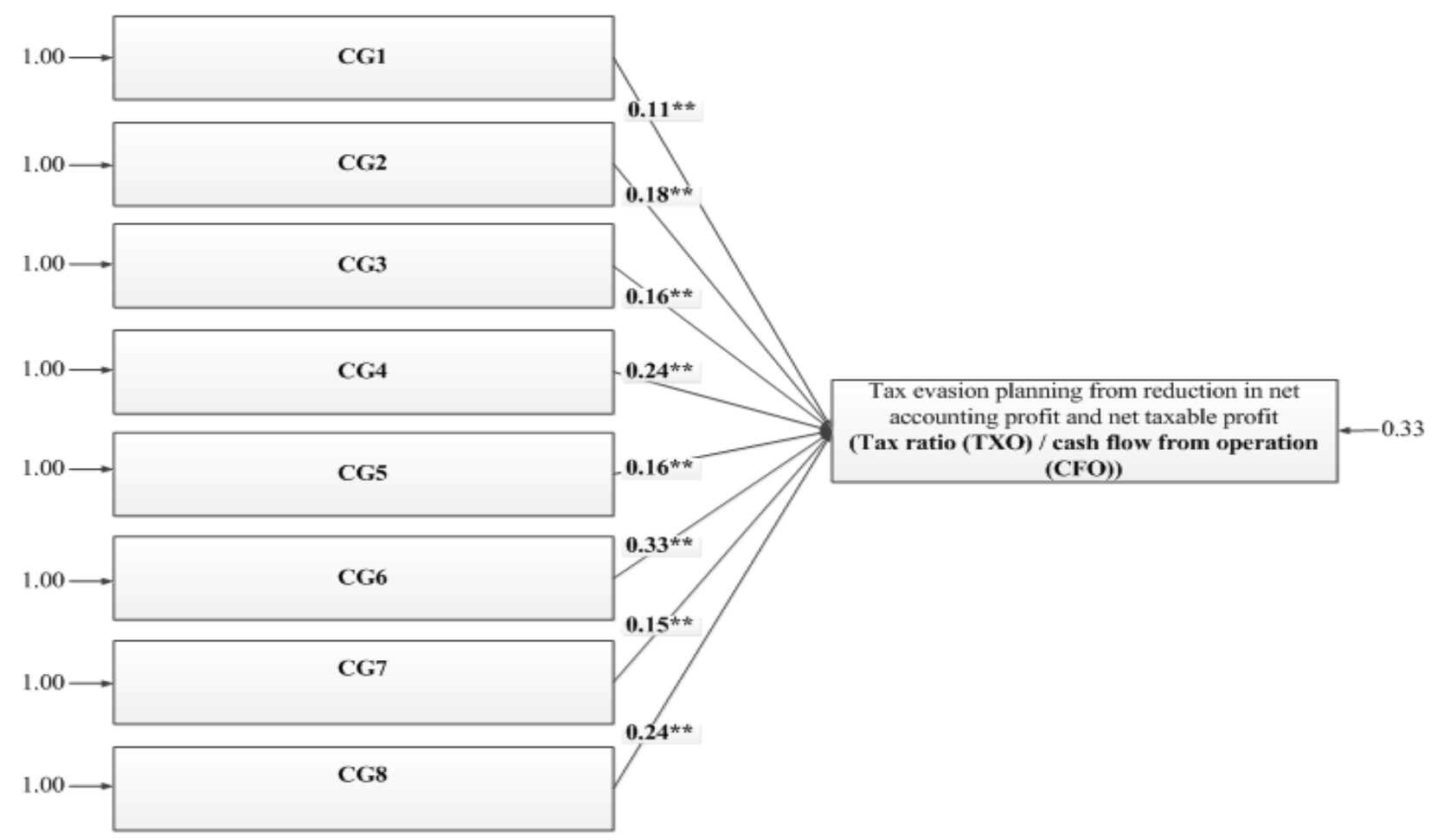

Chi-Square $=0.00$, df $=0$, P-value $=1.00000$, GFI $=1$, AGFI $=1$, RMSEA $=0.000$ Multiple $R=0.74^{* *}$, R Square $=0.55$, Adjusted R Square $=0.52$, Std. Error $=0.26$

In addition, the statistical results were consistent with the research conceptual framework used in the analysis of established empirical data. When the results of the two analyses were compared, the preliminary agreement of statistical analysis with a statistical program was found and allowed to be relevant with the error variance (Wiratchai, 1999, 
p.312). As a result, the research conceptual framework with the established empirical data analysis was consistent with the empirical data collected in this study, as shown in Table 4.

\section{Table 4}

Analysis of conformity index

\begin{tabular}{llll}
\hline Integrity index & Criteria & Measured Index & Evaluation results \\
\hline$\chi^{2} / d f$ & $<2.00$ & $<2.00$ & Meet criteria \\
GFI & $\geq 0.95$ & 1.00 & Meet criteria \\
AGFI & $\geq 0.90$ & 1.00 & Meet criteria \\
RMSEA & $<0.05$ & 0.00 & Meet criteria \\
NFI & $\geq 0.90$ & 1.00 & Meet criteria \\
NNFI & $\geq 0.90$ & 1.00 & Meet criteria \\
CFI & $\geq 0.90$ & 1.00 & Meet criteria \\
SRMR & $<0.05$ & 0.00 & Meet criteria \\
\hline \hline
\end{tabular}

This study concludes that sample companies disclosed more information on corporate governance under the eight principles of good corporate governance 2017. They reduced tax evasion planning that was measured by the tax rate ratio method per cash flow from operating activities. Thus, the $\mathbf{H 1}$ that influence of good corporate governance principles positively affects tax evasion planning from reduction in net accounting profit and net taxable profit, and calculation of TXO per CFO was confirmed.

\subsection{Research findings}

Based on the results of analysis, the influence of good corporate governance has a positive impact on tax evasion planning as per CFO activities. Good corporate governance enabled sample companies to predict tax planning, tax evasion, and tax ratio per CFO at 74 $\%$. An analysis of each aspect of good corporate governance revealed that the eight principles of good corporate governance had a statistically significant positive influence on tax planning evasion towards tax ratio per CFOs at statistically significant level 0.01. CG4 - Ensure effective CEO and people management was at highest level (0.48), followed by CG6 Strengthen effective risk management and internal control (0.28), CG7 - Ensure disclosure 
and financial integrity (0.22), CG5 - Nurture innovation and responsible business (0.21), CG3 - Strengthen board effectiveness and CG8 - Ensure engagement and communication with shareholders (0.19), CG1 - Establish clear leadership role and responsibilities of the board (0.16), and CG2 - Define objectives that promote sustainable value creation (0.15), respectively. The good corporate governance had a statistically significant positive direct influence at statistically significant level 0.01 on tax evasion from reduction in net accounting profit and net taxable profit, and calculation of tax ratio per CFO.

\subsection{Discussion and implication of the results}

Good corporate governance has a positive influence on the tax planning evasion from reduction in net accounting profit and net taxable profit, and calculation of TXO per CFO. The tax evasion planning was measured from tax ratio (TAX) per CFO. Listed companies with good corporate governance tend to reduce tax planning for tax evasion. The tax ratio from operating activities can be lower than tax planning which is consistent with the theory of Desai \& Dharmapata (2006). The principle of tax planning is to reduce the corporate income tax expenses by taking advantage of unclear legal taxation practices. This encourages companies to pay corporate income tax at lower rate or avoid paying corporate income tax also known as tax evasion.

The results of the study are consistent with the theory that when the listed companies disclose good corporate governance underlying eight principles, this can reduce the opportunity in tax evasion planning. Companies enhance higher levels of transparency and credibility with the good corporate governance disclosures. The results are also consistent with the study of Tanchanpong (2014) that when listed companies adopt a tax planning strategy to reduce tax expenses it creates lower operating costs and gain more profits. Therefore, tax planning can affect net accounting profit and decrease net taxable profit based on cash flow from operating activities. Relatively, when the tax planning is increased, it indicates low tax evasion. However, when listed companies pay more attention to disclosing more corporate governance information, companies intend to reduce tax evasion planning.

The results are also consistent with the study of Tanchanpong (2014) that good corporate governance can reduce the company's tax planning and good corporate governance has an influence on its operating performance through tax planning (Tanchanpong, 2015). 
Similarly, results are also consistent with Wahab \& Holland (2012) that good corporate governance scores for independence committees has an influence on the downsizing of tax planning. An increase in independent Executive Committee and corporate governance disclosures reduces tax planning of the listed companies (Klinphanich et al., 2019). This is also consistent with the study of Klinphanich et al., (2019) that listed companies with higher corporate governance disclosure scores are not interested in tax evasion planning. Investors can use information in the corporate governance disclosures to support investment decisions by considering policies and various activities of good corporate governance including transparency and reliability of financial information. Listed companies with a lower tendency to avoid tax evasions disclose more accurate and reliable information in good corporate governance reports. Therefore, listed companies involved in corporate governance and supervision of good corporate governance policy and procedures enable to disclose more useful information in good corporate governance to the public.

The findings of this study suggest that disclosure of good corporate governance has a positive impact on tax evasion planning from reduction in net accounting profit and net taxable profit, and calculation of tax rate ratio with cash flow from operating activities. When corporate governance information is disclosed based on CG Code 2017, listed companies can be labelled a 'fair practice firm' with lower level of tax evasion. This can mean that companies have no intention of tax evasion thus enhancing company's image of transparency and reliability. It encourages other listed companies to pay more attention to disclose good corporate governance following the eight principles of the CG Code 2017. Other listed firms can continuously follow through in order to meet the international standard.

\section{Conclusion, limitation, and recommendation}

Good corporate governance of sample companies listed in the Stock Exchange of Thailand has a positive influence on tax evasion planning from reduction in net accounting profit and net taxable profit. The analysis of tax evasion through ETR and TXO per CFO, disclosed good corporate governance practices under the eight principles of CG Code 2017. Of the eight principles, CG4: Ensure effective CEO and people management was at highest level of the information in corporate governance reports, followed by the CG6: Strengthen effective risk management and internal control, CG7: Ensure disclosure and financial integrity, CG5: Nurture innovation and responsible business, CG3: Strengthen board 
effectiveness, CG8: Ensure engagement and communication with shareholders, CG1: Establish clear leadership role and responsibilities of the board, and CG2: Define objectives that promote sustainable value creation, respectively. Furthermore, good corporate governance had a statistically significant positive direct influence on tax evasion planning and calculation of tax ratio per CFO.

A major limitation of this study was the data collection from the review of corporate governance disclosures of 216 companies listed in the Stock Exchange of Thailand. However, the results could influence policy makers on the disclosure practices. It could encourage listed companies in Thailand to be more involved in good corporate governance disclosures in order to meet international standard. Future research should consider a conduct of an in-depth interview with top management, directors of corporate governance policy and procedure, and/or tax planning managers. Further, samples from multinational companies listed in the stock exchange across different Asian countries with a wider range of internal and external stakeholders can also be considered.

\section{Acknowledgement}

Jutamas Kongsasone would like to thank her advisor, Assistant Professor Dr. Dararat Phoprachak from the Business Administration and Information Technology, Rajamangala University of Technology Suvarnabhumi for providing guidance, valuable advice, and kind support throughout the completion of this study. She is also thankful to all the faculty members of the Business Administration and Information Technology, Rajamangala University of Technology Suvarnabhumi for the valuable knowledge and advice throughout the completion of the research project. Finally, she extends sincerest thanks to Rajamangala University of Technology Suvarnabhumi for providing the opportunity to study the MBA program.

\section{References}

Badetscher, B. A., Phillips, J. D., Pincus, M., \& Olhoft, S. (2009). Earning Management Strategies and The Trade-Off between Tax Benefits and Detection. he Accounting Review, 84(1), 63-97.

Ball, R., \& Shivakumar, L. (2005). Earnings uality in U.K. private firms:comparative loss recognition timeliness. Journal of Accounting and Economics, 39(1), 83-128. 
Chantadech, K. (2018). Good corporate governance principles for listed companies in 2017 Journal of Accounting Professions, 14(41), 73-93.

Chen, S., Chen, X., Cheng, Q., \& Shevlin, T. (2010). Are Family Firms more Tax Aggressive than Non-Family Firms? Journal of Financial Economics, 95, 41-61.

Chotsuwan, R., \& Thongkong, S. (2019). Relationship between tax planning and the price of ordinary shares of listed companies in the Stock Exchange of Thailand. RMUTT Global Business and Economics Review, 14(1), 23-36.

Cloyd, B. C. (1995). The Effects of Financial Accounting Conformity on Recommendations of Tax Preparers. Journal of The American Taxation Association, 17(2), 50.

Collins, J., Kemsley, D., \& Lang, M. (1998). Cross-Jurisdictional Income Shifting and Earnings Valuation. Journal of Accounting Research, 36(2), 209-229.

Coppens, L., \& Peek, E. (2005). An Analysis of Earnings Management by European. Journal of International Accounting, Auditing and Taxation, 14(1), 1-17.

Desai, M. A., \& Dharmapata, D. (2006). Corporate Tax Avoidance and High-Powered Incentives. Journal of Financial Economics, 79(1), 145-179.

Dyreng, S. D., Hanlon, M., \& Maydew, E. L. (2007). Long-Run Corporate Tax Avoidance. The Accounting Review, 83(1), 1-38.

Frank, M. M., Lynch, L. J., \& Rego, S. O. (2009). Tax Reporting Aggressiveness and Its Relation to Aggressive Financial Reporting. The Accounting Review, 82(2), 467-496.

Goncharov, I., \& Zimmermann, J. (2006). Earnings Management when Incentives Compete: The Role of Tax Accounting in Russia. Journal of International Accounting Research, 5(1), 41-65.

Hope, O.-K., Ma, M. S., \& Thomas, W. B. (2013). Tax Avoidance and Geographic Earning Disclosure. Journal of Accounting and Economics, 56(2-3), 170-189.

Ibrahim, N. A., Howard, D. P., \& Angelidis, J. P. (2003). Board Members in the Service Industry: An Empirical Examination of the Relationship between Corporate Social Responsibility Orientation and Director Type. Journal of Business Ethics, 47(4), 393401.

Klinphanich, W., Puangyanee, S., Phoprachak, D., \& Jermsittiparsert, K. (2019). Influence of Representative Factors on Tax Planning through Corporate Governance of Listed Companies in the Stock Exchange of Thailand. International Journal of Innovation, Creativity and Change, 7(1), 300-316.

Lanis, R., \& Richardson, G. (2011). The Effect of Board of Director Composition on Corporate Tax Aggressiveness. Journal Account. Public Policy, 30(1), 50-70. 
Mills, L. F. (1998). Book-Tax Difference and Internal Revenue Service Adjustments. Journal of Accounting Research, 36(2), 343-356.

Puangyani, S., Thammasaneh, S., \& Wachirapanyapong, S. (2018). The Report on Corporate Governance for the Good Performance in the view of Investors: A Case Study of Companies listed on the Stock Exchange of Thailand. SSRU Graduate Studies Journal, 11(1), 1-8.

Rego, S. O. (2003). Tax Avoidance Activities of U.S. Multinational Corporations. Contemporary Accounting Research, 20(4), 805-833.

Salawu, R. O., \& Adedeji, Z. A. (2017). Corporate Governance and Tax Planning Among Non-Financial Quoted Companies in Nigeria. Journal of the International Association of African Researchers and Reviewers, 11(3), 42-59.

Srisakonkij, S. (2019). The relationship between tax planning and stock price of listed companies in the Stock Exchange of Thailand RMUTT Global Business and Economics Review, 14(1), 23-36.

Sullivan, M. A. (2004). Data Show Dramatic Shift of Profits to Tax Havens. Tax Notes, 13, 1190-1200.

Tanchanpong, S. (2014). The influence of good corporate governance on listed companies' tax planning listed on the Stock Exchange of Thailand. Accounting Professional Journal, 10(28), 5-18.

Tanchanpong, S. (2015). Good corporate governance influences performance through tax planning of companies listed on the Stock Exchange of Thailand. Journal of the Association of Researchers, 20(2), 105-113.

Thadthiam, N., \& Promma, P. (2020). Relationship between good corporate governance mechanisms and performance of listed companies in the Stock Exchange of Thailand (SET 100). Suthiparithat Journal, 34(109), 150-161.

The Stock Exchange of Thailand. (2012). The principles of good corporate governance For companies registered in 2012 https://www.set.or.th/sustainable_dev/th/cg/files/2013/CGPrinciple2012Thai-Eng.pdf

The Stock Exchange of Thailand. (2017). The principles of good corporate governance for listed companies in 2017. https://www.sec.or.th/cgthailand/TH/Documents/Regulation/CGCode.pdf

Wahab, N. S. A., \& Holland, K. (2012). Tax Planning, Corporate Governance and Equity Value. The British Accounting Review, 44(2), 111-124.

Yamane, T. (1973). Statistics: An Introductory Analysis. Harper and Row.

Zimmerman, J. L. (1983). Taxes and firm size. Journal of Accounting and Economics, 5, $119-149$. 